Bryn Mawr College

Scholarship, Research, and Creative Work at Bryn Mawr

College

Anthropology Faculty Research and Scholarship

Anthropology

2016

\title{
The Organization of Dissonance in Adena- Hopewell Societies of Eastern North America
}

Edward R. Henry

Casey R. Barrier

Bryn Mawr College, cbarrier@brynmawr.edu

Let us know how access to this document benefits you.

Follow this and additional works at: http://repository.brynmawr.edu/anth_pubs

Part of the Archaeological Anthropology Commons

\section{Citation}

E. R. Henry and C. R. Barrier, "The Organization of Dissonance in Adena-Hopewell Societies of Eastern North America," World Archaeology 48.1 (2016): 87-109.

This paper is posted at Scholarship, Research, and Creative Work at Bryn Mawr College. http://repository.brynmawr.edu/anth_pubs/12

For more information, please contact repository@brynmawr.edu. 


\title{
The Organization of Dissonance in Adena-Hopewell Societies of Eastern North America
}

\author{
Edward R. Henry ${ }^{1}$ and Casey R. Barrier ${ }^{2}$
}

\begin{abstract}
:
Social complexity increased dramatically during the Middle Woodland period (ca. 200 BC-AD 500) in Eastern North America. Adena-Hopewell societies during this period built massive burial mounds, constructed complex geometric earthen enclosures, and maintained extensive trade networks in exotic craft goods. These material signatures suggest that coalition and consensus were sustained through social bonds since clear evidence for top-down leadership does not exist in Adena-Hopewell archaeology. Here, a framework grounded in new understandings of heterarchy is used to explore how coalitions were formed, organised, maintained, and/or shifted as a means to coordinate labour and ritual among Middle Woodland Period groups. Through reanalysis of the Wright Mound in Kentucky, and its burial contents, new insights into heterarchical organisation are used to achieve a wider, diachronic understanding of how humans in the past reached, realised, and rearranged forms of consensus and coalition.
\end{abstract}

Keywords: Heterarchy, Dissonance, Adena-Hopewell, Middle Woodland, Eastern North America

The rise of social complexity among Middle Woodland-era Adena-Hopewell societies (ca. 200 BC-AD 500) in Eastern North America was accompanied by the construction of earthen monuments and participation in trade and exchange networks that covered most of the continent (Abrams and Freter 2005; Brose and Greber 1979; Carr and Case 2005; Clay 1991, 1998; Charles and Buikstra 2006; Dancey and Pacheco 1997; Lynott 2009, 2015; Prufer 1964; Railey 1991; Webb and Snow 1945). Monumental earthen burial mounds and geometric ditch-andembankment enclosures symbolise a shift in the ways that people valued the landscape, engaging in communal labour to signify their bonds to it and to each other (Fenton 2001; Railey 1991;

Seeman and Branch 2006). The interconnectedness of people and places across the Eastern Woodlands, evidenced by trade networks for diverse, exotic craft items across the continent, also

\footnotetext{
${ }^{1}$ Department of Anthropology, Washington University in St. Louis

2 Department of Anthropology, Bryn Mawr College, cbarrier@brynmawr.edu
} 
affirms a symbolic shift toward interaction with others, both between and within corporate groups (Caldwell 1964; Wright and Loveland 2015). Furthermore, evidence for ritual practices and iconography suggests that a coherent ideology—comprised primarily of animistic cosmological themes - was widely shared (Beck and Brown 2012; Brown 1997, 2006; Carr and Case 2005; Case and Carr 2008; Carr and McCord 2013, 2014; Romain 2000, 2009).

However, despite the appearance and persistence of Adena-Hopewell social interaction during roughly a millennium, little archaeological evidence exists for vertical or top-down forms of leadership and/or social organisation (Abrams and Le Rouge 2008; Byers 2011; Carr and Case 2005; Henry 2013). In part, archaeologists may be unable to recognise cross-generational inequalities or social structures that fail to conform to familiar models of hierarchically organised complex societies. By the beginning of the Woodland Period, people across the mid-continent were cultivating starchy-seeded native domesticates (Gremillion 1996; Fritz 1990; Mueller 2013; Smith 2001, 2006), yet convincing evidence for a shift towards sedentism has not been found. Middle Woodland groups appear instead to have remained mobile, probably in part due to sustained success in hunting and gathering activities (Beck and Brown 2012; Yerkes 2005, 2006).

The construction of earthen monuments, however, implies a long-term investment in a specific location. Few domestic campsites—none of which exhibits dense midden deposits indicating considerable degrees of sedentism — have been identified in the region (but see Applegate 2013; Burks 2004; Burks and Pederson 2006). Despite some evidence for shared themes in ritual and mortuary practice, as well as craft production, evidence of standardisation is insufficient to indicate full-time craft specialists (Carr 2008a).

Together, these patterns call into question arguments for the existence and influence of hierarchical sociopolitical institutions within Adena-Hopewell society. In the past, archaeologists 
have explored a range of models for Middle Woodland sociopolitical organisation, from chiefly and big-man societies (Braun 1986; Custer 1987; Ford 1974; Shryock 1987; for critiques see Clay 1992; Mainfort 1989), to arguments that Adena-Hopewell leadership was organised through kinship, as decentralised, situational, segmented, and temporary — grounded in and apart from ritual practice (e.g., shamanism and/or local prestige) (Abrams and Freter 2005; Abrams and Le Rouge 2008; Byers 2011; Carr and Case 2005; Carr 2008b; Henry 2013; Henry et al. 2014).

In this article, we investigate the kinds of organisational structure that would have facilitated the impressive feats of, at least momentary, coalition and consensus that are visible in Middle Woodland mound building and exchange. Over several generations mobile foraginggardening groups periodically gathered at distinctive places on the landscape to participate in the construction of monuments that sometimes included interring deceased members of society. This unified separate communities into an organisational lattice where labour and ritual practices were fused to produce monumental earthen constructions (sensu Sherwood and Kidder 2011) that hold elaborate mortuary remains - some of which appear to be aligned with astronomical movements (see Romain 2000, 2015). In our view, the degrees of coordination, knowledge, and consensus evident in the activities of these Woodland Period societies requires reconsideration of the models and analogies used to explain social complexity. Below, we refocus attention on the mechanisms through which consensus was materialised and coalitions were formed using new insights into heterarchy. Specifically, we will consider how kin-based and heterarchically organised coalitions (Crumley 1987, 1995, 2005, 2007; DeMarrais 2007, 2013; McIntosh 1999) facilitated the ongoing management of conflicting interests, changing patterns of territoriality, access to material wealth and other resources, and the construction of knowledge (both sacred 
and otherwise). Understanding how these processes unfolded is important because they ultimately led to the creation of more stable communities during the Middle Woodland.

We argue, following Trautmann et al. (2012), that kinship is performed and hence that social ties require ongoing maintenance. A focus on kinship highlights the ways that consensus was negotiated and maintained among Adena-Hopewell coalitions during fluid, temporary, and situational gatherings. By examining the role of kinship in these coalitions, we draw attention to the processes through which situational leadership and influence were organised in a heterarchical manner. We elaborate on heterarchy by drawing upon the recent work of economic sociologist David Stark (2009). Stark's discussion focuses on the ways that historically-centered evaluative dimensions of worth can lead to change. His emphasis rests upon elucidating the ways that heterarchies organise dissonance: the tensions that arise when two unusual or unsuitable elements of society are encountered. From this perspective dissonance can be considered a creative social tension because it entails the constant discovery of new mechanisms to manage temporary and situational influence and control (importantly, we claim, both horizontally and through time), a classic hallmark of heterarchical organisation (Stark 2009:23-27). Especially for societies lacking institutional hierarchies, consideration of how groups created and managed dissonance helps us understand the processes through which temporary coalitions could be understood to form, operate, and be abandoned, and can help us envision how positions of leadership and authority ebbed and flowed across groups/individuals, as well as through time.

We apply these ideas to a case study from the Middle Ohio River Valley of Eastern North America, at the heartland of the Adena-Hopewell region. Specifically, we assess the utility of this approach through re-analysis of the Wright Mound site (Webb 1940) (Figure 1). Located in Kentucky's Bluegrass Region, the Wright Mound was traditionally classified as Adena (Clay 
1991, 1998; Rafferty 2005; Shryock 1987); however, new research on the Adena phenomena indicates that the typological separation from Hopewell is less useful. "Adena" and "Hopewell" sites arguably overlapped in time and space (see contributions to Applegate and Mainfort 2005; Clay 2014; Henry 2011; Lepper et al. 2014). In this article, our use of the term "AdenaHopewell" reinforces our attention on the broader fluorescence of social complexity at this time, rather than the time-space taxonomic units.

\section{Material Patterns of Middle Woodland Kinship}

Kinship was likely a major element in the organisation of small-scale Adena-Hopewell societies (Byers 2011; Clay 1998; Carr and Case 2005; Cobb 1993). The shared construction costs of earthen monuments still dotting the landscape are a testament to the capacities of kinbased coalitions to complete such monuments—some in a single episode. Moreover, memorialisation of particular deceased community members within burial mounds suggests that remembering ancestors, and maintaining long-lasting kin-based alliances, were important aspects of building social consensus at a wider scale.

Sahlins (2001a, 2011b, 2013:2, 18, 20) has recently characterised kinship as a "mutuality of being" that occurs when people "participate in one another's existence." Through the acts of participating and being intrinsic to another person's web of kinship, people generate complex networks of being (Sahlins 2011a, 2011b). Comparison of mtDNA results from burial mounds in the Lower Illinois and Ohio River Valleys supports this view of Middle Woodland kinship patterns by suggesting that social networks crosscut biological differences and linked these two regions together via exchange of ritual practices and ideological beliefs (Bolnick and Smith 2007, Mills 2003). Therefore, defining kinship as participatory engagement among social groups during the Middle Woodland in Eastern North America may not be inaccurate. Exploring the 
ways that kinship structures were organised to facilitate lateral arrangements of diverse leadership roles remains important for characterising the heterogeneity of Middle Woodland sociality. Because a high degree of material and symbolic variation has been documented in Adena-Hopewell sites, we suggest that attention given to notions of accountability and worth in heterarchical organisations (Stark 2009) provides a fresh approach for understanding how fluid and situational social positions are (re)produced as well as recognised (in burial practices) over time. That is, as individuals assumed temporary leadership positions their actions and levels of success would have been assessed by others, leading to real-time evaluations of their accountability to the group to perform important roles (e.g., organising and leading hunts or ritual ceremonies, obtaining exotic materials and/or crafting important items, etc.). An individual's worth to the group would have increased as positive accountability was sustained over their lifetime. The temporary and situational status positions of worthy individuals, therefore, could be translated into durable forms of memorialisation, such as access to monumental burial or material wealth.

\section{Searching for Accountability and Worth in Middle Woodland Heterarchies}

Variability in mortuary practices, mound building, and the construction of geometrically enclosed spaces, as well as the crafting of ritual regalia, suggests that aspects of heterarchical organisation were present in Middle Woodland societies (Abrams and Freter 2005; Abrams and Le Rouge 2008; Henry 2013; Henry et al. 2014). While heterarchy has been explored at some length in archaeological discourse, distinct misconceptions remain. Foremost among these is the idea that heterarchy is an alternative to hierarchy.

Heterarchy became prominent with the rise of artificial intelligence and computer programming and coding that crossed program boundaries instead of operating within a single, 
hierarchically structured network. ${ }^{3}$ After Carole Crumley's (1979:144-145) application of heterarchy to archaeological data, some utilised the concept as a structural alternative to hierarchy, despite explicit attempts to highlight the distinctive, lateral forms of organisation that lend themselves to an ongoing process of ranking (i.e., hierarchical) and unranking (i.e., nonhierarchical). Crumley later reiterated this emphasis on process, stating that, in heterarchical organisations, temporary hierarchical leadership may arise, later transforming to non-hierarchical expressions of authority when the situations that required leadership changed or came to an end (Crumley 1995:4).

In modern contexts, heterarchy is employed in archaeology to explain heterogeneity in a variety of contexts (e.g., architectural, sociopolitical, scalar, geographic, and artistic) (Abrams and Le Rouge 2008; Byers 2011; DeMarrais 2011, 2013; Henry 2013; see also contributions to Ehrenreich et al. 1995 and Kohring and Wynne-Jones 2007). However, a lack of exploring how heterarchy plays out in practice has led some researchers to seek alternative models for heterogeneous complexity. For example, Renfrew and Cherry's (1986) ideas about peer-polity interaction examined how separate but laterally organised sociopolitical units respond to social and technological change through competition and emulation. Frachetti's $(2009,2012)$ nonuniform complexity model explains interactions between societies that participated differently in the same institutions during the Bronze Age in Eurasia (e.g., pastoralists and agriculturalists participating one another's subsistence economies). Frachetti's work in particular asks important questions of heterarchies, including how, when, and under what conditions their members comply with authority in certain situations while withdrawing compliance in others.

\footnotetext{
${ }^{3}$ For historical references on heterarchy see Crumley (1979), McCulloch (1945), and Stark (2009:19-31).
} 
While Crumley and Stark share interests in understanding how heterarchies operate, Stark (2009) places emphasis on the temporal ordering of accountability and worth in people and institutions. He pays particular attention to the ways dissonance acts as a creative tension that requires institutions to be structured in a manner that makes certain they endure through the actions of agents. As Stark writes:

[d]issonance occurs when diverse, even antagonistic, performance principles overlap. The manifest, or proximate, result of this rivalry is a noisy clash, as the proponents of different conceptions of value contend with each other. The latent consequence of this dissonance is that the diversity of value-frames generates new combinations of... resources... It is the friction at the interacting overlap of multiple performance criteria that generates productive recombinations by sustaining a pragmatic organizational reflexivity. (Stark 2009:27)

In our Middle Woodland example, dissonance may arise as multiple groups entering a temporary coalition differentially value leadership roles and evaluate worth. This is especially true where institutionalised hierarchies are absent, as groups are reluctant to submit to the directives of others. In this situation, consensus to comply with a worthy individual and their close supporters will depend upon the task at hand, leading to a complex and overlapping network of shifting power and influence through time. The temporary and shifting forms of leadership positions that are the hallmark of heterarchical organisations are, we argue below, visible in the Middle Woodland archaeological record through the different ways that groups came together to memorialise certain individuals during moments of aggregation and communal mound construction.

Stark's ethnographic case studies can be instructive for our purposes, if only to visualise how these principles can operate on more familiar terms. For instance, he describes a socialist machine factory in Hungary where workers produce for the state at a set wage during regular hours, but promote a coalition-run market-based machining business in the same space after- 
hours. The dissonance that rises between the ongoing daily shift between socialist to capitalist enterprises, and from positions of authority and compliance to situational positions of influence in the after-hours operation, necessitates novel management forms organised heterarchically. Each individual must prove their accountability as they pass through positions of prominence and back, engaging in different tasks requiring completion (e.g., blueprint creation, raw material acquisition, and production). Workers rally around the lead of particular individuals in these situations so they can push an order out the door or complete one stage of manufacture so the next can begin. The more effective and efficient a stage leader is, the more accountable they are to the system, and their worth increases throughout the coalition. This example of heterarchical organisation, grounded in consensus, shows how ongoing performance-based evaluations of accountability and worth perpetuate the existence of situational leadership (Figure 2).

Stark's emphasis on the social creativity born from dissonance in heterarchical structures is something that we find compelling for archaeological examinations of variability within smallscale coalitions. Our adoption of Stark's ideas places emphasis on the successes that accountability affords people in situationally demanding social roles. The notion of dissonance helps define ways that tentative social practices materialise into customs that solve tensions arising among agents in heterarchical coalitions. Moreover, it helps us understand how such processes are enacted. Coming to consensus in heterarchical structures helps establish organisational boundaries for groups of individuals who have different ways of evaluating worth (sensu Boltanski and Thévenot 1999). Although dissonance can provide the impetus for redefining these boundaries, their maintenance indicates that negotiations for temporary and situational influence over other possibilities were successful. 
Archaeologically these social phenomena might be expressed through the stabilisation of variability in architectural forms, mortuary treatments, trade networks, or style within craft items. The perpetuation of an ongoing "new normal" in these material phenomena could be considered as evidence for the active management of dissonance as long as the coalition is being reproduced. Archaeological contexts where we find it advantageous to apply these concepts include the investigation of ongoing variability in kinship processes (Beck 2007; Cobb 1993; Gillespie and Joyce 2000), territoriality (Van Valkenburgh and Osborne 2012), the construction and maintenance of group architecture (both monumental and otherwise) (Thompson and Pluckhahn 2012; Wright 2014), and trade and exchange networks associated with small-scale craft production (Wright and Loveland 2015) —all evidence for the collective action and labour (Carballo 2012; Carballo et al. 2013) required to reproduce coalitions and manage dissonance. In what follows, we employ Stark's notion of dissonance to assess ways that Adena-Hopewell societies organised and reorganised themselves in relation to issues of accountability and worth, as assessed through communal labour management, monumentalisation, and ritual practice.

\section{The Organisation of Dissonance at Wright Mound, Kentucky}

The Wright Mound (Webb 1940), situated in Kentucky's Bluegrass Region, provides a case study for investigating collective action and the organisation of dissonance, as it is manifested in a sacred mortuary locale. Below, we assess patterns of labour, ritual practice, age, gender, and access to material wealth and social capital as correlates for heterarchical forms of social organisation, as discussed above. Our aim is to determine how this approach can explain aspects of the archaeological record that have formerly not been well understood ${ }^{4}$. Prior to its

\footnotetext{
${ }^{4}$ While we employ the age and sex determinations originally reported by Hertzberg (in Webb 1940), we recognise that recent re-examinations of other Middle Woodland burial remains have recognised errors in earlier classifications (see Milner and Jefferies 1991). Reanalysis of the Wright burial remains using contemporary analytical methods may also lead, in the future, to adjustments.
} 
excavation during the late 1930s, Wright Mound represented the largest Adena mound in Kentucky (Figure 3), standing 9.5 meters tall with a basal diameter of approximately 60 meters. Wright mound's excavations revealed $14 \log$ tombs and 21 burials. Excavation director William S. Webb (1940:17) identified 18 of the 21 burials as log tomb burials. One of the early North American archaeologists who worked to standardise excavation methods, Webb's careful and meticulous records allow us to reconsider the complex history of sub-mound use and to analyse variation among the mortuary features that belong to each of the mound's four construction phases.

Only two radiocarbon dates, performed on charcoal recovered from two distinct contexts, exist for Wright Mound (Crane and Griffin 1972:160). The anomalous nature of these dates when calibrated may result from early sampling and 14C techniques (Table 1). However, Rafferty (2005:168), among others, has argued that the date straddling AD 200 best represents its chronological placement, indicating contemporaneity with "Late Adena" and "Hopewell" sites. As a result, the historical trajectory of the coalition represented at Wright Mound can be traced through stratigraphic analyses of monument construction and the sequence of interments.

At least seven structures (six circular, one rectangular) had been built in the area underlying the primary mound (Figure 4). Webb described this activity area as a village midden, although the internal areas of the structures are large and little obvious evidence for roof supports or domestic features was found. Thus, it is unlikely that people lived here on a regular basis (Table 2). Instead, the structures were probably Adena paired-post ritual structures-screen-like enclosures arguably used for non-mortuary, or ancillary mortuary, activities (Clay 1987, 1998, 2014; Purtill et al. 2014). Evidence for episodic gatherings and collective ritual suggests that social consensus was built through the assembling of members of kin-based coalitions for rituals 
at a communal locale. At the center of this dense scatter suggesting repetitive rituals the initial mound was constructed. This phase enclosed six individuals; two who were placed in log tombs. In general, log tombs are considered defleshing crypts for some people but also locales where particular individuals became interred, adding to interpretations that they are resting places for specific people rather than cemeteries (Brown 1979; Charles and Buikstra 2002). These features are constructed with earthen ramps leading to cavities where logs are positioned in a variety of ways that enclose the body (Figure 5).

Disarticulated remains near at the interface of the midden and first mound phase comprised two burials in the initial mound phase. They had no associated grave goods. One burial (19) was placed in a bark-lined pit, another in a log platform tomb with a snake skeleton (Burial 11). An elaborate rectangular pit log tomb held another. One more individual was decapitated and placed at the edge of this rectangular pit (Figure 6a). The age and sex of most of these primary interments is not known; however, both individuals in log-tomb features were male, the first a mature adult and the second a juvenile/child. These two individuals had more mortuary accouterments than other burials in this phase. Detailed descriptions of the burials (for each phase) can be found in Table 3.

During the second phase of mound construction, an additional six individuals were interred. A single simple pit burial (Figure 6b) contained an individual of unknown age and sex placed upon, and sealed with, prepared puddled clay but with no grave goods. The other individuals included both adult males and adult females sealed in log tombs with a wide range of exotic goods that included copper bracelets, shell disk beads, marginella beads, and a limestone pipe. Red ocher was smeared on two of the log tomb burials (one female and one male) 
belonging to this construction phase; one of these was interred with a snake skeleton. A simple pit burial (\#9) was wrapped in animal skins and decapitated.

As part of the third phase of construction, four adult males and two adult females were placed in log tombs. Webb attributes the discrete skull of a mature adult male, found accompanying an adult female (burial 6) in a log tomb, to the category of "unprepared" burial (Figure 6c; Table 3). In this phase both grave goods and the variability of tomb form increased to include new shapes, evidenced by a change to include rectangular and circular forms. Two adult females interred during the third phase were placed with an increased amount of exotic mortuary materials in comparison to earlier phases (e.g., shell disk and marginella beads, copper bracelets, and also a crescent-shaped copper headdress). The female with the copper headdress was interred with an infant. Males were placed primarily with bone or shell items. A single log tomb that contained an adult male was void of crafted grave goods.

The fourth and final construction phase contained only three burials (Figure 6d). An individual of unidentifiable age and sex was placed with shell beads in a simple pit lined with bark. Two log tomb burials contained large quantities, and a greater diversity, of elaborately decorated items (e.g., shell beads, copper bracelets, whetstones, whelk shells, mica crescents and other mica forms). One of the latter interments was an adolescent female, the other an adult of unknown sex.

We argue that each individual buried in Wright Mound had been selected for particularly distinctive mortuary treatment. In general, Adena-Hopewell mounds such as Wright Mound are not seen as community cemeteries due to the low numbers of interments relative to the populations needed for their construction. Therefore, we argue that the coalition at Wright Mound considered individuals buried there worth the time, labour, materials, and symbolism 
invested in them after their deaths. Significantly, this interpretation need not imply that these people had high status during their lives. Paraphrasing Parker Pearson (1982, 1999), among others, the dead do not bury themselves. At the same time, we argue that burials with notable differences in labour, grave goods, and symbolic elaboration should not be overlooked. Someone selected and arranged particular ritual practices and treatments for these individuals. In the next section, we discuss the ways that concepts of heterarchy and dissonance can shed light on the differential mortuary treatments and practices visible in the Wright Mound burial assemblage.

\section{Discussion}

We suggest the submound deposits at Wright show evidence that over time (possibly multiple generations) social groups were meeting to erect ritual post enclosures and to engage in communal activities (e.g., feasting, initiation rites, and mortuary events). Further, variation in the ways interments were constructed (i.e., pits and tombs), as well as diversity in the type and amount of materials placed in them through the sequential construction phases at Wright Mound, suggest that we can trace archaeologically changes in how Wright members managed dissonance in their coalition. Evidence for movement toward social consensus is suggested by the presence of large postholes and the thick, midden-like, refuse deposit described by Webb (1940:48-53). The absence of prepared hearths, storage pits, and substantial roof supports reinforces this interpretation of the space as a ritual location. Moreover, Webb (1940:52) observed that many of the posts were refilled with this midden-like soil, indicating that the structures were probably dismantled or pulled down after temporary use.

An increase in episodic ritual activities may have been a response to the need to maintain both group autonomy and mobility in the face of intensifying pressures of territoriality related to changes in trade and exchange relationships, hunting patterns, and gardening areas (Charles and 
Buikstra 1983, 2002). Periodic congregation and the construction of communal facilities suggest that a corporate group was coalescing in this area of the Bluegrass landscape. As this group materialised its presence through ritual practices centered on the paired-post structures, the boundaries of communal property became more visible, with shared rights and responsibilities, and notions of descent and kinship also becoming more clearly demarcated.

In our view, this coalescent assembly created opportunities for dissonance. With new forms of social interaction and ritual, individuals could be evaluated and held accountable for their actions by the coalition. Those situations where the authority of individuals was recognised, and growing more durable, likely corresponded to contexts where experience, knowledge, and personal relationships helped exploit particular situations (e.g., hunting, ritual events, access to exotics) and the attainment of worth through consensus (see Figure 2). We suggest that the creative tensions embedded within dissonance afforded diverse mechanisms of evaluation that were at play in the Wright group as individuals entered and exited positions of prominence. The dissonance occurring when previously unrelated (or differently related) groups entered into social bonds was also the creative force structuring heterarchical organisation and structural change. Examination of those interred in the mound can provide insights into how the Wright coalition evaluated particular autonomous kin groups and individuals, as well as how strategies for evaluating worth changed through time.

Webb (1940:48-49) notes difficulty in separating the sub-mound activity area from the primary mound because the midden-like matrix of the sub-mound deposits was collected for mound fill for phase one. This stratigraphic puzzle implies continuity from pre-mound activity to mound-building ritual practices. In addition, the creation of the mound over this locale would have solidified the presence of the coalition on this location through permanent architecture. 
Within phase one, six individuals were interred; their varied burial treatments represent dissonance. A mature adult and a child/juvenile, both males placed in log tombs, shows that kin groups may have been negotiating for access to mound burial based on a shared, rather than individual, sense of worth to the coalition. We consider this one way to negotiate dissonance with novel mortuary customs. Recent research on Early Woodland cave use near this region suggests that juvenile males were being initiated into different social roles through cave-bounded ritual traditions (Crothers 2012). If similar pan-gender processes were occurring within the Wright coalition, this might clarify how kin groups negotiated for young individuals to gain mound interments. The access to material wealth seen in Burials 11, 19, and 21 imply that they were valued by Wright society. Nevertheless, unprepared burials in phase one are also important because the Wright group evaluated them as having enough worth to grant them a monumental interment. These individuals lack similar associated burial goods; however, their placement implies a degree of consensus-based worth to the Wright coalition at this early phase. At this point, dissonance may have been managed by providing mound burials to individuals whose contributions were highly diverse.

The treatment of interments within phase two of Wright Mound shows less overall diversity. Although the sample sizes are small, we tentatively suggest that the sex ratios in this phase indicate that gender was becoming more important as an axis of variation for the evaluation of worth. The presence of only adults in these burials further suggests that age (implying experience or knowledge) was important as a measure of worth. The individual in burial nine was associated with the lowest values for labour input and material wealth. This individual, whose sex and age remain unknown, was buried with his/her head placed between the knees, then wrapped in skins and sealed in a bark-lined pit with puddled clay above and below. 
The symbolism that accompanied this individual suggests their influence and worth could have extended in to the spiritual domain. Other log tomb burials in phase two suggest that access to material wealth was relatively equal across genders. Burials 13 (adult female) and 15 (adult male), both exhibiting varying amounts of material wealth (see Table 3), were smeared with red ocher. We consider this evidence that, like access to log tomb interments, symbolic treatments and wealth were also accorded to both genders. Overall, the phase-two burials present little evidence for hierarchical ordering although differences in symbolism may identify individuals who held distinct positions, had special skills or knowledge, or were valued by the coalition for other reasons.

In phase three, the burial treatments changed again, materialising ideas of dissonance, flexible social organisation, and further variation in the ways that ideas of worth were evaluated within Adena-Hopewell society. Six burials (four adult males and two adult females) were placed in log tombs, with substantial increases in the distribution of associated items. Additionally, a new log tomb type with no precedent (circular) was introduced, enclosing an adult female buried with an adult male's skull. A new artifact category was also introduced during this stage: a copper crescent headdress placed in an adult female burial (burial 17). We consider these innovations to signal a considerable increase in material wealth, seen in the preparation of log tombs and in the amount and diversity of craft items.

Following Stark (2009), these changes might indicate an escalation, or shift, in dissonance within Wright society that was managed through burial treatments. For example, some log tomb interments (e.g., the male in burial 16) involved comparable labour expenditure with other burials in phase three, yet without the addition of exotic grave goods. This individual may have been judged as worthy using new criteria of accountability that accompanied changing 
social relations or intensified ritual practices. In addition, burial 8 (an adult male) may have been valued for a particular kind of knowledge, given the presence of bone tools and stone pipes in his grave. The accumulated evidence emphasises lateral differences (such as distinct roles), rather than hierarchical ranking or status differentiation.

Finally, during phase four, a decline in the number of burials suggests that dissonance increased and judgments of worth narrowed. Only two elaborate log tomb interments and one bark lined burial were uncovered. The log tomb burials included an adolescent female and an adult of unknown sex, while the third individual was of unknown age and sex. As Wright Mound's final interments we propose that their presence suggests increasing limitations being placed on access to a monumental interment. Accountability and worth for some members in Wright society might have experienced a divergent shift away from consensus, while others did not. Symbolic treatments bestowed upon burials in the final phase are evidenced in red ocher and the first, and only, appearance of whelk shell within the mound. The adolescent female in this stage (Burial 1) indicates that worth in this phase was embodied, at least in part, through a mixture of material acquisition and symbolic treatments. However, access to these treatments was not as prevalent in phase four when compared with previously identified phases and interments.

In reviewing the varied nature of burial treatments over four phases of construction at Wright Mound, we have tried to illustrate how a heterarchically-ordered coalition might make changing judgments about the worth of its members. We have argued that, in a heterarchy, individuals frequently come into contact with others through novel situations that required innovative solutions to problems. Dissonance in heterarchical structures, as highlighted by Stark, reveals a fluid, shifting, and varied social landscape, where the accountability, and ultimately 
worth, of an individual depends upon their creativity, their skill, their knowledge, their authority, their ability to resolve conflicts, and (perhaps most importantly) their continued assessment by others. Instead of judging Middle Woodland kin groups as either egalitarian or hierarchical, we argue that the Wright Mound data indicate both were possible, as measures of worth — and the accountability of particular members - in changing situations was negotiated. Individuals judged worthy were likely to be memorialised, albeit in a manner that was idiosyncratic, flexibly determined by situation, person, and problem.

\section{Conclusions}

If the coalition that built and used the Wright Mound had developed hierarchical social institutions over time, we would have expected to find fewer interments per construction phase, more standardised and repetitive mortuary treatments, and greater homogeneity in labour inputs and grave goods. Instead, Wright Mound had six interments during the first three phases of mound construction and only three in the last. Visible differences in (1) the labour required to build log tombs; (2) the age and gender of those buried; as well as (3) differential access to material wealth and symbolic treatments (e.g., red ocher, placement with particular animal remains, among other things) suggests it was not only single elites who were afforded monumental interments. Moreover, the presence of subadults, as well as more simple burials in bark lined clay pits, indicates that some individuals were given a mound burial for reasons that may relate more to the perceived accountability and worth of their immediate kin rather than their own.

Do the latter individuals represent people whose worth was measured by skill, knowledge, and/or experiences in life? We argue that their presence might signal lateral or situational forms of influence, in a society in which interaction — and evaluation — was based upon regular face-to- 
face interactions in and apart from ritual settings. We have argued that those buried in the mound were individuals who were valued within their networks, or whose living relatives advocated for special mortuary treatments. Burial of members of society who had access to material wealth or influence, alongside those with evidence for symbolic treatments reflects dissonance in the form of divergent and fluid ideas of accountability and worth in the heterarchical social environment of the Middle Woodland.

This approach to understanding how dissonance is a process of re-organisation and transformation of heterarchical structures provides a window into the dynamics of Middle Woodland societies of Eastern North America. By understanding how kin-ordered coalitions permitted temporary opportunities for individuals to gain influence or to wield authority, we can begin to characterise the fluid and flexible nature of social organisation and consensus-building in small-scale coalitions. Perhaps most importantly, the recognition of these dynamics of accountability highlights the diversity of roles, and the ways they were valued, in heterarchies of the past.

\section{Acknowledgments}

We would like to thank the editor of this issue, Dr. Elizabeth DeMarrais, for her unending encouragement and guidance throughout the review process. She provided helpful comments, made us think through particular ideas we present, and helped us work out particular aspects of dissonance that hopefully make our paper more digestible for other archaeologists. Three anonymous reviewers also provided very helpful suggestions that clarified our paper and many of the arguments we make. Dr. Ruth Van Dyke also provided very kind and helpful reflections on an earlier presentation at the 2014 meeting of American Anthropological Association where these ideas first materialised. The Kentucky Archaeological Survey was kind in allowing us to use Jimmy Railey's artwork here, as was the William S. Webb Museum of Anthropology at the University of Kentucky for allowing use of excavation photographs from Wright Mound. Finally, we thank our "friendleagues" (friend + colleague) Dr. Alice P. Wright and David W. Mixter, whose ideas, fun perspectives on archaeology and life, and work inspire us. 
Table 1. Radiocarbon dates and their contexts from Wright Mound reported in Crane and Griffin (1972). Calibrations made using OxCal v4.2 (Bronk Ramsey 2009) and the IntCal13 calibration curve (Reimer et al. 2013).

\begin{tabular}{|c|c|c|c|c|c|}
\hline $\begin{array}{c}\text { Sample } \\
\text { No. }\end{array}$ & Context & Material & $\begin{array}{c}\text { Uncalibrated } \\
\text { RCYBP }\end{array}$ & $\begin{array}{c}\text { Calibrated } \\
1 \sigma\end{array}$ & $\begin{array}{c}\text { Calibrated } \\
2 \sigma\end{array}$ \\
\hline $\mathrm{n} / \mathrm{a}$ & $\begin{array}{l}\text { Charred logs } \\
\text { covering } \\
\text { primary mound }\end{array}$ & $\begin{array}{c}\text { Wood } \\
\text { Charcoal }\end{array}$ & $1900 \pm 50$ & AD $30-210$ & AD $2-236$ \\
\hline M-2238 & $\begin{array}{c}\text { Stage 2; Burial } \\
13\end{array}$ & $\begin{array}{c}\text { Wood } \\
\text { Charcoal }\end{array}$ & $1740 \pm 140$ & AD $90-427$ & $\begin{array}{c}20 \mathrm{BC}-\mathrm{AD} \\
596\end{array}$ \\
\hline
\end{tabular}

Table 2. List of submound structures and diameters after Webb 1940:50. See also Figure 4.

$\begin{array}{cccc}\begin{array}{c}\text { Structure } \\ \text { No. }\end{array} & \begin{array}{c}\text { Diameter } \\ (\mathbf{m})\end{array} & \begin{array}{c}\text { Length } \\ (\mathbf{m})\end{array} & \begin{array}{c}\text { Width } \\ (\mathbf{m})\end{array} \\ 1 & 31.39 & \mathrm{n} / \mathrm{a} & \mathrm{n} / \mathrm{a} \\ 2 & 18.13 & \mathrm{n} / \mathrm{a} & \mathrm{n} / \mathrm{a} \\ 3 & 11.27 & \mathrm{n} / \mathrm{a} & \mathrm{n} / \mathrm{a} \\ 4 & 33.52 & \mathrm{n} / \mathrm{a} & \mathrm{n} / \mathrm{a} \\ 5 & 11.58 & \mathrm{n} / \mathrm{a} & \mathrm{n} / \mathrm{a} \\ 6 & 35.35 & \mathrm{n} / \mathrm{a} & \mathrm{n} / \mathrm{a} \\ 7 & \mathrm{n} / \mathrm{a} & 10.97 & 12.19\end{array}$


Table 3. Relevant burial data from Wright Mound after Webb 1940:20-22.

\begin{tabular}{|c|c|c|c|c|c|c|}
\hline $\begin{array}{c}\text { Burial } \\
\text { No. }\end{array}$ & Estimated Age & $\begin{array}{l}\text { Estimated } \\
\text { Sex }\end{array}$ & Type of Grave Prep. & $\begin{array}{c}\text { Mound } \\
\text { Stage }\end{array}$ & Material Accomp. & Symbolic Treatment \\
\hline 10 & $\mathrm{n} / \mathrm{a}$ & $\mathrm{n} / \mathrm{a}$ & unprepared & 1 & $\mathrm{n} / \mathrm{a}$ & $\mathrm{n} / \mathrm{a}$ \\
\hline 11 & mature adult & male & log platform tomb & 1 & 2-copper bracelets; shell disk beads & snake skeleton \\
\hline 12 & $\mathrm{n} / \mathrm{a}$ & $\mathrm{n} / \mathrm{a}$ & unprepared & 1 & $\mathrm{n} / \mathrm{a}$ & $\mathrm{n} / \mathrm{a}$ \\
\hline 19 & $\mathrm{n} / \mathrm{a}$ & $\mathrm{n} / \mathrm{a}$ & simple bark-lined pit & 1 & shell disk beads & $\mathrm{n} / \mathrm{a}$ \\
\hline 20 & $\mathrm{n} / \mathrm{a}$ & $\mathrm{n} / \mathrm{a}$ & unprepared & 1 & $\mathrm{n} / \mathrm{a}$ & decapitated \\
\hline 21 & juvenile/child & male & $\begin{array}{l}\text { rectangular pit log } \\
\text { tomb }\end{array}$ & 1 & $\begin{array}{c}\text { 1-copper bracelet; marginella beads; shell disk } \\
\text { beads }\end{array}$ & $\mathrm{n} / \mathrm{a}$ \\
\hline 5 & adult & female & $\begin{array}{l}\text { rectangular pit log } \\
\text { tomb }\end{array}$ & 2 & 2-copper bracelets; shell disk beads & $\mathrm{n} / \mathrm{a}$ \\
\hline 9 & $\mathrm{n} / \mathrm{a}$ & $\mathrm{n} / \mathrm{a}$ & simple pit & 2 & $\mathrm{n} / \mathrm{a}$ & $\begin{array}{l}\text { wrapped in skins; } \\
\text { decapitated }\end{array}$ \\
\hline 13 & adult & female & $\begin{array}{l}\text { rectangular pit log } \\
\text { tomb }\end{array}$ & 2 & shell disk beads & red ocher \\
\hline 14 & mature adult & male & $\log$ box tomb & 2 & 1-copper bracelet; shell disk beads & $\mathrm{n} / \mathrm{a}$ \\
\hline 15 & adult & male & $\begin{array}{l}\text { rectangular pit log } \\
\text { tomb }\end{array}$ & 2 & $\begin{array}{l}\text { 2-copper bracelets; shell disk beads; } 1 \text { - } \\
\text { limestone tubular pipe }\end{array}$ & red ocher \\
\hline 18 & mature adult & male & $\begin{array}{l}\text { rectangular pit log } \\
\text { tomb }\end{array}$ & 2 & 4-copper bracelets; shell disk beads; & snake skeleton \\
\hline 3 & adult & $\begin{array}{l}\text { possible } \\
\text { male }\end{array}$ & $\log$ box tomb & 3 & shell disk beads & $\mathrm{n} / \mathrm{a}$ \\
\hline 6 & adult & female & circular log tomb & 3 & $\begin{array}{l}\text { 4-copper bracelets; shell disk beads; } \\
\text { marginella beads }\end{array}$ & $\mathrm{n} / \mathrm{a}$ \\
\hline 7 & mature adult & male & extra skull in B. 6 & 3 & $\mathrm{n} / \mathrm{a}$ & $\mathrm{n} / \mathrm{a}$ \\
\hline 8 & adult & male & $\log$ box tomb & 3 & $\begin{array}{l}\text { 2-bone combs; 2-stone tubular pipes; 3-bone } \\
\text { spatulae }\end{array}$ & $\mathrm{n} / \mathrm{a}$ \\
\hline 16 & adult & male & $\log$ box tomb & 3 & $\mathrm{n} / \mathrm{a}$ & $\mathrm{n} / \mathrm{a}$ \\
\hline 17 & adult & female & $\log$ platform tomb & 3 & $\begin{array}{l}\text { 2-copper bracelets; copper cresentic headdress; } \\
\text { shell disk beads }\end{array}$ & placed with infant \\
\hline 1 & adolescent & female & $\log$ box tomb & 4 & $\begin{array}{l}\text { 4-copper bracelets; mica cresent; shell disk } \\
\text { beads; sandstone whetstone; whelk shell }\end{array}$ & $\mathrm{n} / \mathrm{a}$ \\
\hline 2 & adult & $\mathrm{n} / \mathrm{a}$ & $\log$ platform tomb & 4 & 4-copper bracelets; mica & red ocher \\
\hline 4 & $\mathrm{n} / \mathrm{a}$ & $\mathrm{n} / \mathrm{a}$ & simple pit & 4 & shell disk beads & $\mathrm{n} / \mathrm{a}$ \\
\hline
\end{tabular}




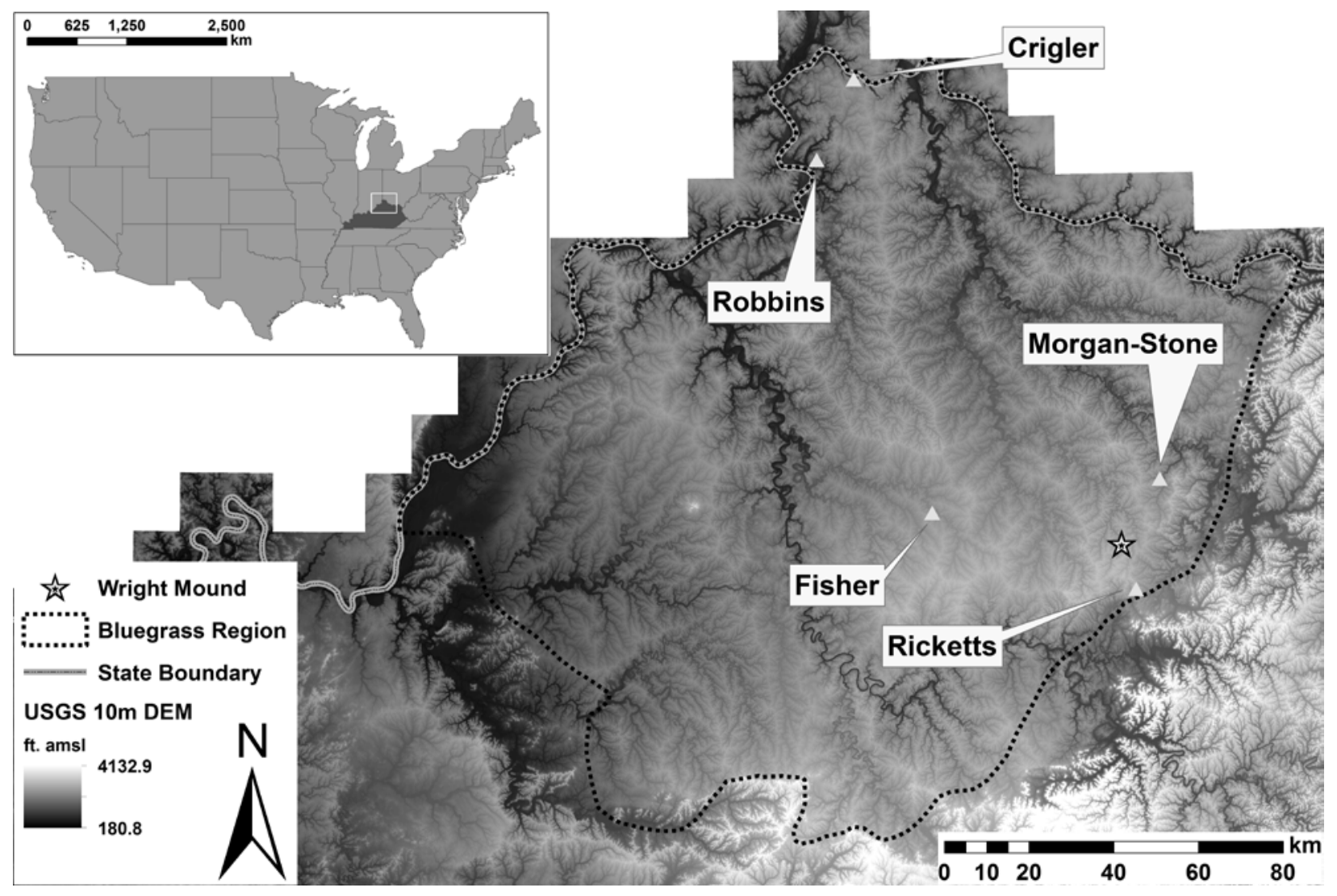

Figure 1. The location of Wright Mound and other well-known Adena-Hopewell burial mounds in Kentucky's Bluegrass Region that were excavated with Depression-era funds by William S. Webb and his colleagues. 
Time/Situation A

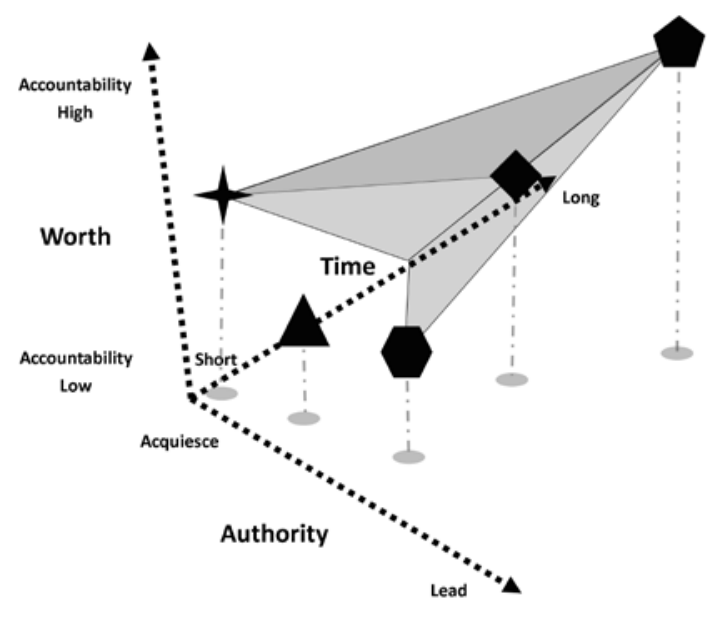

Positions of Leadership/Influence

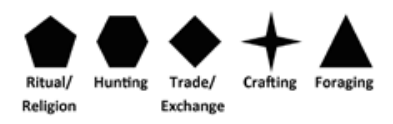

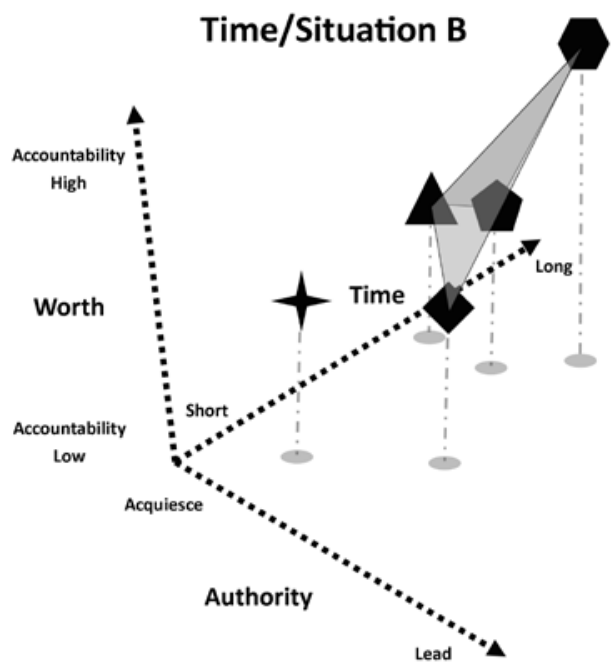

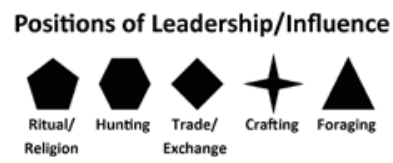

Figure 2. Schematic of heterarchically organised structures described here, where knowledge, experience, accountability, and worth, as well as the ability to gain support from other persons of authority provide durable and longer lasting influence. Gray areas represent connections between influential individuals. Situation A resembles the connections a person with accountability in the ritual/religious sphere might make with other persons of authority to successfully organise and conduct a ceremonial event. In this situation the leader's connections to other positions of the network create the opportunity for elevated positions of authority in domains of feasting and exotic goods production and exchange. Situation B resembles different connections one might need to form during a seasonal hunting event. Ritual/religion is still at play here but not the primary emphasis, as knowledge of exchange is required to ensure members adequately receive the appropriate yields of the hunt with respect to their particular social role. 


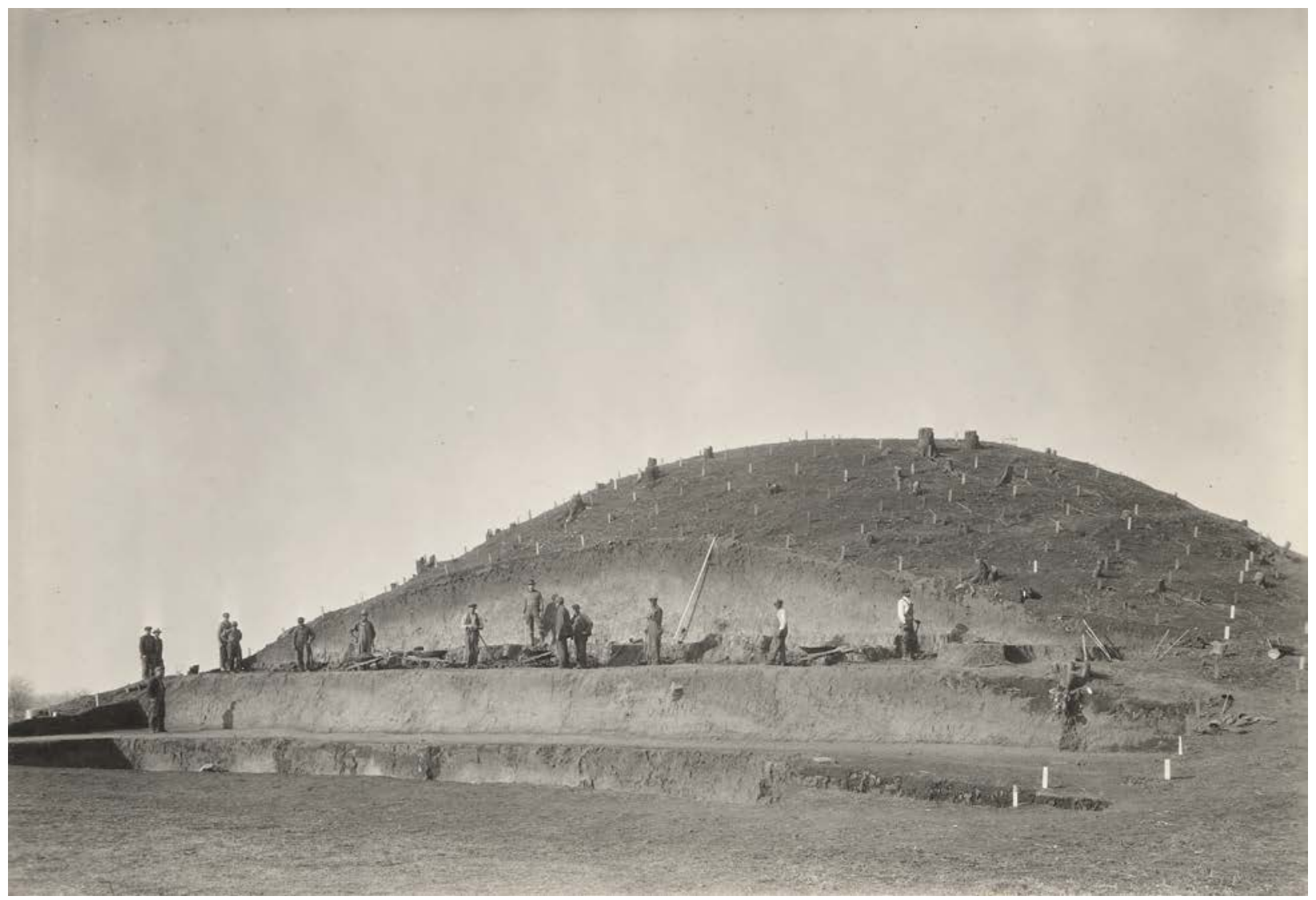

Figure 3. View of the Wright Mound from south showing men working on the 50-foot profile. Photograph taken February 5, 1938. Image used courtesy of the William S. Webb Museum of Anthropology at the University of Kentucky. 


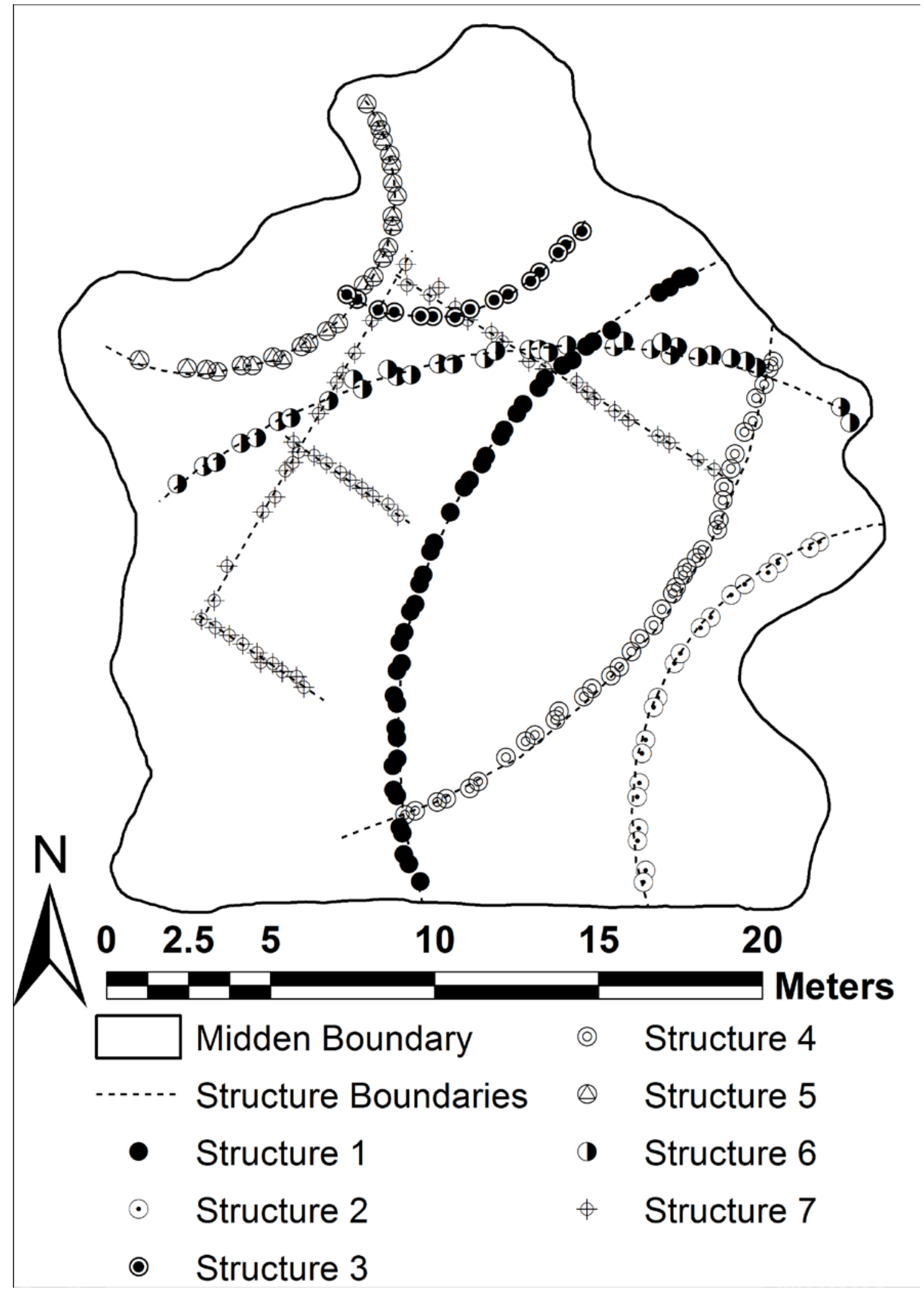

Figure 4. Map of paired-post structures found beneath Wright Mound. Redrawn after Webb 1940:51, Figure 33. 


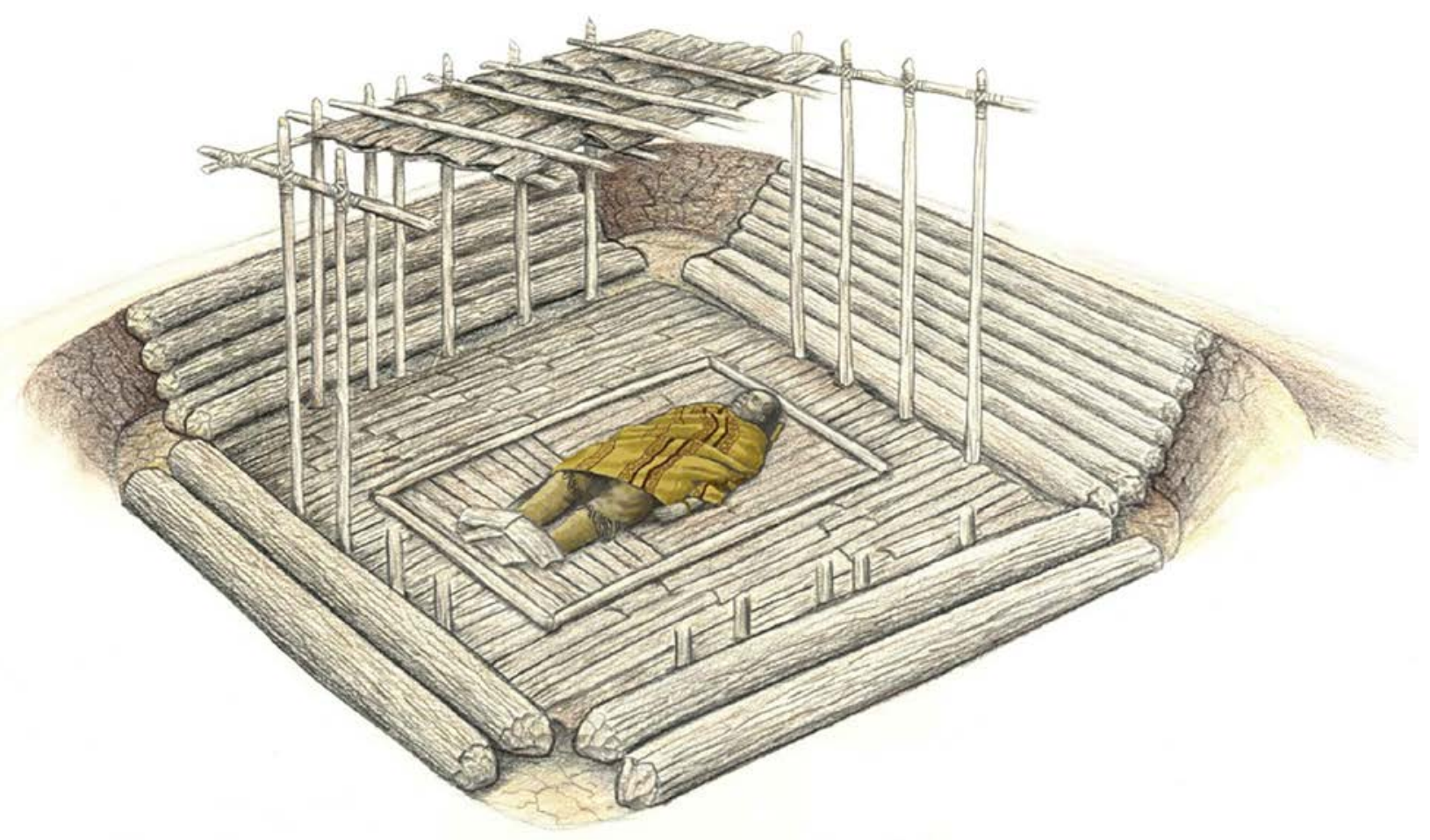

Figure 5. An artist's depiction of a log tomb burial from Wright Mound (Henderson and Schlarb 2007). Artwork modeled after Feature 22, Burials 20 and 21 (Webb 1940:44). Original artwork by Jimmy A. Railey, used here courtesy of the Kentucky Archaeological Survey. 

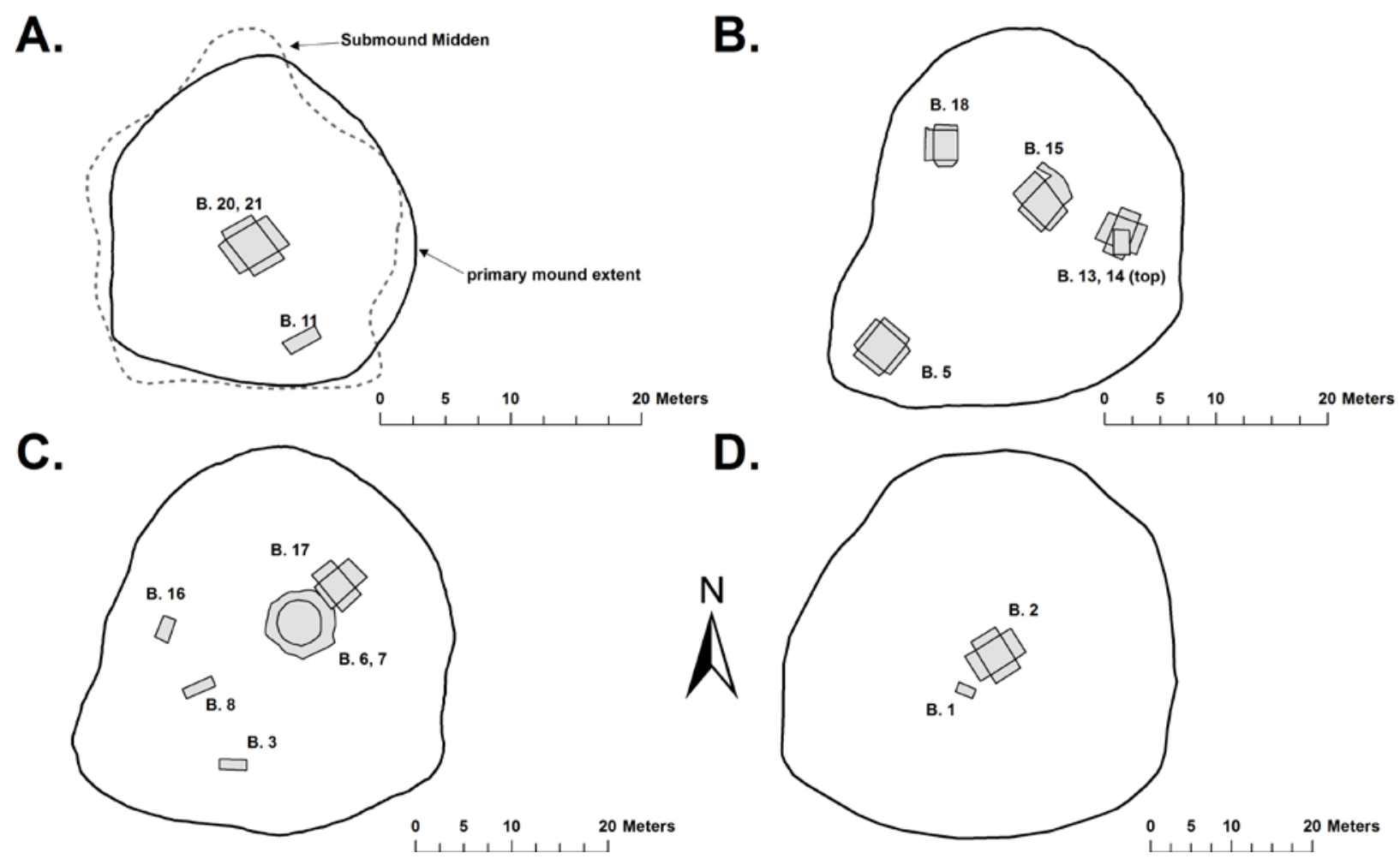

Figure 6. (a.) Primary mound phase and burial locations in relation to the submound midden. (b.) Phase two and burial locations. (c.) Phase three and burial locations. (d.) Phase four and burial locations. 


\section{Bibliography}

Abrams, E. M. and Freter, A. C. eds. 2005. The Emergence of the Moundbuilders: The Archaeology of Tribal Societies in Southeastern Ohio, Ohio University Press, Athens.

Abrams, E. M. and Le Rouge, M. F. 2008. Political Complexity and Mound Construction Among the Early and Late Adena of the Hocking Valley, Ohio. In M. P. Otto and B. G. Redmond eds., Transitions: Archaic and Early Woodland Research in the Ohio Country, Ohio University Press : In association with the Ohio Archaeological Council, Athens, pp. 214-231.

Angelbeck, B., and Grier, C. 2012. Anarchism and the Archaeology of Anarchic Societies: Resistance to Centralization in the Coast Salish Region of the Pacific Northwest Coast. Current Anthropology 53(5): 547-587.

Applegate, D. 2013. The Early-Middle Woodland Domestic Landscape in Kentucky. In A. P. Wright and E. R. Henry eds., Early and Middle Woodland Landscapes of the Southeast, University Press of Florida, Gainesville, pp. 19-44.

Applegate, D. and Mainfort, R. C. eds. 2005. Woodland Period Systematics in the Middle Ohio Valley, University of Alabama Press, Tuscaloosa.

Beck, R. A., ed. 2007. The Durable House: House Society Models in Archaeology. Center for Archaeological Investigations, Southern Illinois University.

Beck Jr., R. A. and Brown, J. A. 2012. Political Economy and the Routinization of Religious Movements: A View from the Eastern Woodlands. Archeological Papers of the American Anthropological Association 21: 72-88.

Bolnick, D. A. and Smith, D. G. 2007. Migration and Social Structure among the Hopewell: Evidence from Ancient DNA. American Antiquity 72: 627-644.

Boltanski, L. and Thévenot, L. 1999. The Sociology of Critical Capacity. European Journal of Social Theory 2: 359-377.

Braun, D. P. 1986. Midwestern Hopewellian Exchange and Supralocation Interaction. In C. Renfrew and J. F. Cherry eds., Peer Polity Interaction and Socio-Political Change, Cambridge University Press, Cambridge, UK; New York, pp. 117-126.

Brose, D. S. and Greber, N. eds. 1979. Hopewell Archaeology: The Chillicothe Conference, Kent State University Press, Kent, Ohio.

Brown, J. A. 1979. Charnel houses and mortuary crypts: disposal of the dead in the Middle Woodland period. Hopewell Archaeology: The Chillicothe Conference, Brose DS, Greber N (eds). The Kent State University Press: Kent, OH; 211-219. 
Brown, J. A. 1997. The Archaeology of Ancient Religion in the Eastern Woodlands. Annual Review of Anthropology 465-485.

Brown, J. A. 2006. The Shamanic Element in Hopewell Period Ritual. In D. K. Charles and J. E. Buikstra eds., Recreating Hopewell, University Press of Florida, Gainesville, pp. 475488.

Burks, J. D. 2004. Identifying Household Cluster and Refuse Disposal Patterns at the Strait Site: A Third Century A.D. Nucleated Settlement in the Middle Ohio River Valley, The Ohio State University.

Burks, J. D. and Pederson, J. 2006. The Place of Nonmound Debris at Hopewell Mound Group 33RO27, Ross County, Ohio. In D. K. Charles and J. E. Buikstra eds., Recreating Hopewell, University Press of Florida, Gainesville, pp. 376-401.

Byers, A. M. 2011. Sacred Games, Death, and Renewal in the Ancient Eastern Woodlands: The Ohio Hopewell System of Cult Sodality Heterarchies, AltaMira Press, Lanham.

Caldwell, J. R. 1964. Interaction Spheres in Prehistory. In J. R. Caldwell and R. L. Hall eds., Hopewellian Studies, Illinois State Museum, Springfield, pp. 133-143.

Carballo, D. M. ed. 2012. Cooperation and Collective Action: Archaeological Perspectives, University Press of Colorado.

Carballo, D. M., Roscoe, P. and Feinman, G. M. 2013. Cooperation and Collective Action in the Cultural Evolution of Complex Societies. J Archaeol Method Theory 1-36.

Carr, C. 2008a. Coming to Know Ohio Hopewell Peoples Better: Topics for Future Research, Masters' Theses, and Doctoral Dissertations. The Scioto Hopewell and Their Neighbors: Bioarchaeological Documentation and Cultural Understanding, Springer, New York, N.Y., pp. 603-690.

Carr, C. 2008b. Social and Ritual Organization. In D. T. Case and C. Carr eds., The Scioto Hopewell and Their Neighbors: Bioarchaeological Documentation and Cultural Understanding, Springer, New York, N.Y., pp. 151-288.

Carr, C. and Case, D. T. eds. 2006. Gathering Hopewell: Society, Ritual, and Interaction, Kluwer Academic/Plenum Publishers, New York.

Carr, C. and McCord, R. 2013. Ohio Hopewell Depictions of Composite Creatures: Part IBiological Identification and Ethnohistorical Insights. Midcontinental Journal of Archaeology 38: 5-81.

Carr, C. and McCord, R. 2015. Ohio Hopewell Depictions of Composite Creatures: Part IIArchaeological Context and a Journey to an Afterlife. Midcontinental Journal of Archaeology 40: 18-47. 
Case, D. T. and Carr, C. 2008. The Scioto Hopewell and Their Neighbors: Bioarchaeological Documentation and Cultural Understanding, Springer, Berlin.

Charles, D. K. and Buikstra, J. E. 2002. Siting, Sighting, and Citing the Dead. In H. Silverman and D. Small, eds., The Space and Place of Death. Archeological Papers of the American Anthropological Association, Arlington, Va., pp. 13-25.

Charles, D. K. and Buikstra, J. E. 1983. Archaic Mortuary Sites in the Central Mississippi Drainage: Distribution, Structure, and Behavioral Implications. In J. Phillips and J. Brown, eds., Archaic Hunter and Gatherers in the American Midwest. NY: Academic Press, pp. 117-45.

Charles, D. K. and Buikstra, J. E. eds. 2006. Recreating Hopewell, University Press of Florida, Gainesville.

Clay, R. B. 1987. Circles and Ovals: Two Types of Adena Space. Southeastern Archaeology 6: 46-56.

Clay, R. B. 1991. Adena Ritual Development: An Organizational Type in a Temporal Perspective. In C. Stout and C. K. Hensley eds., The Human Landscape in Kentucky's Past: Site Structure and Settlement Patterns, Kentucky Heritage Council, Frankfort, pp. 30-39.

Clay, R. B. 1992. Chiefdoms, Big Men, or What? Economy, Settlement Patterns, and Their Bearing on Adena Political Models. In M. F. Seeman ed., Cultural Variablity in Context: Woodland Settlements of the Ohio Valley, Kent State University Press, Kent, Ohio, pp. 77-80.

Clay, R. B. 1998. The Essential Features of Adena Ritual and Their Implications. Southeastern Archaeology 17: 1-21.

Clay, R. B. 2014. What Does Mortuary Variability in the Ohio Valley Middle Woodland Mean? Agency, Its Projects, and Interpretive Ambiguity. Southeastern Archaeology 33: 143152.

Crane, H. R. and Griffin, J. B. 1972. University of Michigan Radiocarbon Dates XIV. Radiocarbon 14: 155-194.

Crothers, G. 2012. Early Woodland Ritual Use of Caves in Eastern North America. American Antiquity 77: 524-541.

Crumley, C. L. 1979. Three Locational Models: An Epistemological Assessment for Anthropology and Archaeology. Advances in Archaeological Method and Theory 141173. 
Crumley, C. L. 1995. Heterarchy and the Analysis of Complex Societies. Archeological Papers of the American Anthropological Association 6: 1-5.

Crumley, C. L. 2005. Remember How to Organize: Heterarchy Across Disciplines. In C. S. Beekman and W. W. Baden eds., Nonlinear Models in Archaeology and Anthropology: Continuing the Revolution, Ashgate, Burlington, VT, pp. 35-50.

Crumley, C. L. 2007. Notes on a New Paradigm. In S. Kohring and S. Wynne-Jones eds., Socialising Complexity: Structure, Interaction, and Power in Archaeological Discourse, Oxbow, Oxford, U.K., pp. 30-36.

Custer, J. F. 1987. New Perspectives on the Delmarva Adena Complex. Midcontinental Journal of Archaeology 12: 33-53.

Dancey, W. S. and Pacheco, P. J. eds. 1997. Ohio Hopewell Community Organization, Kent State University Press.

DeMarrais, E. 2011. Figuring the Group. Cambridge Archaeological Journal 21: 165-186.

DeMarrais, E. 2013. Understanding Heterarchy: Crafting and Social Projects in Pre-Hispanic Northwest Argentina. Cambridge Archaeological Journal 23: 345-362.

Ehrenreich, R. M., Crumley, C. L. and Levy, J. E. eds. 1995. Heterarchy and the Analysis of Complex Societies, American Anthropological Association.

Fenton, J. P. 2001. Early Woodland Burial Mounds of Kentucky: Symbolic Elements in the Cultural Landscape. In L. P. Sullivan and S. C. Prezzano eds., Archaeology of the Appalachian Highlands, University of Tennessee Press, Knoxville, pp. 137-148.

Ford, R. I. 1974. Northeastern Archeology: Past and Future Directions. Annual Review of Anthropology 3: 385-413.

Frachetti, M. D. 2009. Differentiated Landscapes and Non-uniform Complexity among Bronze Age Societies of the Eurasian Steppe. In B. K. Hanks and K. M. Linduff eds., Social Complexity in Prehistoric Eurasia: Monuments, Metals, and Mobility, Cambridge University Press, New York, New York, pp. 19-46.

Frachetti, M. D. 2012. Multiregional Emergence of Mobile Pastoralism and Nonuniform Institutional Complexity across Eurasia. Current Anthropology 53: 2-38.

Fritz, G. J. 1990. Multiple Pathways to Farming in Precontact Eastern North America. Journal of World Prehistory 4: 387-435.

Joyce, R. A. and Gillespie, S. D. eds. 2000. Beyond Kinship: Social and Material Reproduction in House Societies. University of Pennsylvania Press. 
Gremillion, K. J. 1996. Early Agricultural Diet in Eastern North America: Evidence from Two Kentucky Rockshelters. American Antiquity 61: 520-536.

Henderson, A. G., and E. J. Scharlb. 2007. Adena: Woodland Period Moundbuilders of the Bluegrass. Education Series 9. Lexington: Kentucky Archaeological Survey.

Henry, E. R. 2011. A Multistage Geophysical Approach to Detecting and Interpreting Archaeological Features at the LeBus Circle, Bourbon County, Kentucky. Archaeological Prospection 18(4): 231-244.

Henry, E. R. 2013. Working Out Adena Political Organization and Variation from the Ritual Landscape in the Kentucky Bluegrass. In A. P. Wright and E. R. Henry eds., Early and Middle Woodland Landscapes of the Southeast, University Press of Florida, Gainesville, pp. 219-233.

Henry, E. R., Laracuente, N. R., Case, J. S. and Johnson, J. K. 2014. Incorporating Multistaged Geophysical Data into Regional-Scale Models: A Case Study from an Adena Burial Mound in Central Kentucky. Archaeological Prospection 21: 15-26.

Kohring, S. and Wynne-Jones, S. 2007. Socialising Complexity: Structure, Interaction and Power in Archaeological Discourse, Oxbow Books.

Lepper, B. T., Leone, K. L., Jakes, K. A., Pansing, L. L. and Pickard, W. H. 2014. Radiocarbon Dates on Textile and Bark Samples from the Central Grave of the Adena Mound 33RO1, Chillicothe, Ohio. Midcontinental Journal of Archaeology 39: 1-21.

Lynott, M. 2015. Hopewell Ceremonial Landscapes of Ohio: More Than Mounds and Geometric Earthworks, Oxbow Books.

Lynott, M. J. ed. 2009. In the Footprints of Squier and Davis: Archaeological Fieldwork in Ross County, Ohio, National Park Service: Midwest Archaeological Center, Lincoln, Nebraska.

Mainfort, R. C., Jr. 1989. Adena Chiefdoms? Evidence from the Wright Mound. Midcontinental Journal of Archaeology 14: 164-178.

McCulloch, W. S. 1945. A Heterarchy of Values Determined by the Topology of Nervous Nets. Bulletin of Mathematical Biophysics 7(2):89-93.

McIntosh, S. K. 2005. Beyond Chiefdoms: Pathways to Complexity in Africa, Cambridge University Press.

Mills, L. A. 2003. Mitochondrial DNA Analysis of the Ohio Hopewell of the Hopewell Mound Group, The Ohio State University. 
Pearson, M. P. 1982. Mortuary Practices, Society, and Ideology: An Ethnoarchaeological Study. In I. Hodder ed., Symbolic and Structural Archaeology, Cambridge University Press, New York, NY, pp. 99-114.

Pearson, M. P. 2000. The Archaeology of Death and Burial, Texas A\&M University Press.

Prufer, O. H. 1964. The Hopewell Cult. Scientific American 211: 90-102.

Purtill, M. P., Norr, J. A. and Frodge, J. B. 2014. Open-Air "Adena” Paired-Post Ritual Features in the Middle Ohio Valley: A New Interpretation. Midcontinental Journal of Archaeology 39: 59-82.

Rafferty, S. M., Applegate, D. and Mainfort Jr, R. C. 2005. The Many Messages of Death: Mortuary Practices in the Ohio Valley and Northeast. Woodland Period Systematics in the Middle Oiho Valley, University of Alabama Press, Tuscaloosa, pp. 150-167.

Railey, J. A. 1991. Woodland Settlement Trends and Symbolic Architecture in the Kentucky Bluegrass. In C. Stout and C. K. Hensley eds., The Human Landscape in Kentucky's Past: Site Structure and Settlement Patterns, Kentucky Heritage Council, Frankfort, pp. 56-77.

Romain, W. F. 2000. Mysteries of the Hopewell: Astronomers, Geometers, and Magicians of the Eastern Woodlands, University of Akron Press.

Romain, W. F. 2009. Shamans of the Lost World: A Cognitive Approach to the Prehistoric Religion of the Ohio Hopewell, AltaMira Press.

Romain, W. F. 2015. An Archaeology of the Sacred: Adena-Hopewell Astronomy and Landscape Archaeology. The Ancient Earthworks Project, Olmsted Falls, OH.

Sahlins, M. 2011a. What Kinship Is (part One). Journal of the Royal Anthropological Institute 17: $2-19$.

Sahlins, M. 2011b. What Kinship Is (part Two). Journal of the Royal Anthropological Institute 17: 227-242.

Sahlins, M. 2013. What Kinship Is-And Is Not, University Of Chicago Press, Chicago.

Seeman, M. F. and Branch, J. L. 2006. The Mounded Landscapes of Ohio: Hopewell Patterns and Placements. In D. K. Charles and J. E. Buikstra eds., Recreating Hopewell, University Press of Florida, Gainesville, pp. 106-121.

Shryock, A. J. 1987. The Wright Mound Reexamined: Generative Structures and the Political Economy of a Simple Chiefdom. Midcontinental Journal of Archaeology 12: 243-268.

Smith, B. D. 2001. Low-Level Food Production. Journal of Archaeological Research 9: 1-43. 
Smith, B. D. 2006. Eastern North America as an Independent Center of Plant Domestication. Proceedings of the National Academy of Sciences 103: 12223-12228.

Stark, D. 2009. The Sense of Dissonance: Accounts of Worth in Economic Life, Princeton University Press, Princeton, N.J.; Woodstock.

Thompson, V. D. and Pluckhahn, T. J. 2012. Monumentalization and Ritual Landscapes at Fort Center in the Lake Okeechobee Basin of South Florida. Journal of Anthropological Archaeology 31(1): 49-65.

Trautmann, T. R., Feeley-Harnick, G., and Mitani, J. C. 2012. Deep Kinship. In A. Shryock and D. L. Smail eds., Deep History: The Architecture of the Past and Present, University of California Press, Berkeley, pp. 160-188.

Van Valkenburgh P. and Osborne, J. F. 2012. Home Turf: Archaeology, Territoriality, and Politics. Archeological Papers of the American Anthropological Association 22(1): 1-27.

Webb, W. S. 1940. The Wright Mounds, Sites 6 and 7, Montgomery County, Kentucky, University of Kentucky, Lexington, KY.

Webb, W. S. and Snow, C. E. 1945. The Adena People, University of Kentucky, Lexington.

Wright, A. P. 2014. History, Monumentality, and Interaction in the Appalachian Summit Middle Woodland. American Antiquity 79(2): 277-294.

Wright, A. P. and Loveland, E. 2015. Ritualised Craft Production at the Hopewell Periphery: New Evidence from the Appalachian Summit. Antiquity 89: 137-153.

Yerkes, R. W. 2005. Bone Chemistry, Body Parts, and Growth Marks: Evaluating Ohio Hopewell and Cahokia Mississippian Seasonality, Subsistence, Ritual, and Feasting. American Antiquity 70: 241-265.

Yerkes, R. W. 2006. Middle Woodland Settlements and Social Organization in the Central Ohio Valley: Were the Hopewell Really Farmers? In D. K. Charles and J. E. Buikstra eds., Recreating Hopewell, University Press of Florida, Gainesville, pp. 50-61. 